\title{
Depletion of the floodplain-channel complex of the river (Belaya river, Republic of Bashkortostan)
}

\author{
Elvira Nafikova ${ }^{1}$, Dmitry Alexandrov ${ }^{1, *}$, Anastasia Platonova ${ }^{1}$, Kamila Gayanova $^{1}$, and \\ Kamilla Chuvashaeva ${ }^{1}$ \\ ${ }^{1}$ Ufa State Aviation Technical University, Karla Marksa str., 12, 450000, Ufa, Russia
}

\begin{abstract}
The article presents a comprehensive assessment of the geoecological risk of the Belaya River floodplain (Republic of Bashkortostan, Russia). The risk assessment of the floodplain-channel complex includes the risk of depletion by the plant species composition and the risk of depletion of the ecological and hydrological states. Geographic information maps of the floodplain were compiled for vegetation and floodplain forests and wetlands. The extent of forest cover was chosen as an indicator of the floodplain's resilience to the risk of depletion and decline. The calculation of the risk of depletion of floodplains based on the ecological and hydrological state was carried out taking into account the changes in floodplain areas over the past 10 years, data on the catchment of ground and surface waters, "sealed" areas and the annual average discharge. The assessment and zoning of the river floodplain territory was carried out according to the proposed method.
\end{abstract}

\section{Introduction}

The normal functioning of the floodplain channel complex is an important factor in the general geoecological state of the river basin. The floodplain-bed complex is an interconnected self-developing actively functioning system, where the bed and the floodplain are its components. The floodplain-riverbed complexes possess all the features of natural complexes - they are territorially and genetically uniform, the processes occurring in them are interconnected, and geographical objects or complexes of a lower rank (subsystems) arise as a result of these processes affecting each other. For thousands of years, floodplains have been a place of settlement formation and farming. These functions remain to be the main ones for many modern landscapes.

The relevance of the study of river floodplains is due to the need to optimize the use of natural resources, to reduce the effect of anthropogenic pressure on the environment. High environmental tension is often caused by a lack of knowledge and, consequently, an underestimation of the geographic patterns of distribution and manifestations of natural processes [1].

\footnotetext{
* Corresponding author: dmutruurus@gmail.com
} 
The adoption of environmental management issues derive from a number of problems of methodical and methodological nature: the uncertainty of the criteria for assessing the ecological state of floodplains and water bodies; multifaceted nature of the interconnections of quantitative and qualitative characteristics of the floodplain-riverbed complex due to regional natural, anthropogenic and climatic features of the territory.

Several scientific studies are known to discuss mainly the ecological state of the watercourse [2] or only the territory of the floodplain soil [3], as well as general multicomponent risk parameters of the flooding and pollution vulnerabilities of river floodplains, such as assessing the basin in the northern coastal zone of the Black Sea (Romanian sector) [4], taking into account the climatic changes [1] or depending on anthropogenic interference and development of the floodplain [5,6]. In [7], a review and ranking of methods for assessing floodplains for different types of watercourses is carried out, and it is noted that in the management of water resources and floodplain-channel complexes it is important to a perform an integral and multicomponent assessment. Scientific works [8-12] show how the use of geographic information systems allows integrating a large amount of data on floodplain territories and issuing a multilateral comprehensive assessment.

The aim of this study is to assess the risk of depletion of the floodplain-riverbed complex of the Belaya River using geoinformation modeling methods to identify areas of floodplains that are most prone to degradation and where environmental management measures need to be taken.

The Belaya River is the main waterway of the Republic of Bashkortostan and, at the same time, an example of a water body that has been subject to anthropogenic impact for a long time. In this regard, the problem of the depletion of its floodplain-riverbed complex becomes relevant.

Due to the complexity of the object of study, it is proposed to conduct a comprehensive risk assessment, which includes assessing the risk of flood depletion by plant species composition and calculating the risk of depletion of floodplains according to the ecological and hydrological state. When calculating the said risk, the parameters taken in are the following: the floodplain area change, data on the catchment of ground and surface waters, data on the vegetation and forest cover of the territory, artificially created areas, and the long-term average annual discharge.

\section{Assessment of the risk of flood depletion by plant species composition}

When calculating the risk of quantitative depletion of floodplain-riverbed complexes, it is proposed to take in the features of the use of the territory: arable land, forest cover, artificially created areas, etc.

Based on the spatial data of GIS vegetation of the Republic of Bashkortostan, informational maps have been developed on the species composition of vegetation and forest cover in the floodplain areas of the Belaya River. The ratios of the areas of different types of forest cover (oak-steppe forests, floodplain cherry-alder forests, dark-coniferous broad-leaved forests, etc.) to the area of the floodplains of the rivers under study are determined Table 1 .

A graphical example of the zoning of the studied floodplain areas according to the plant species composition is presented in Figure 1.

Many researchers [13-15] classify floodplain forests as the highest protection classes, highlighting their coastal, soil protection, water conservation, colmatizing, and channel forming roles. The previous destruction of forests in the valleys and catchment areas of the 
rivers entailed the intensification of erosion processes in the floodplain itself, manifesting in the form of riverbank erosion, the erosion of the floodplain surface and the drift cones.

Table 1. The ratio of the areas of various types of vegetation to the area of the studied floodplainriver complexes of the Belaya River, in $\%$.

\begin{tabular}{|c|c|c|c|c|c|c|c|c|}
\hline $\begin{array}{l}\text { River Type of } \\
\text { forest cover }\end{array}$ & Belaya & $\begin{array}{l}\text { Bystry } \\
\text { Tanyp }\end{array}$ & Sim & Inzer & Dema & Ashkadar & Nougos & Ufa \\
\hline $\begin{array}{l}\text { dark coniferous } \\
\text { broad-leaved } \\
\text { forests }\end{array}$ & 1,10 & 16,32 & 0,00 & 0,00 & 0,00 & 0,00 & 0,00 & 0,00 \\
\hline $\begin{array}{l}\text { floodplain bird } \\
\text { cherry and alder } \\
\text { forests }\end{array}$ & 21,20 & 0,05 & 58,22 & 44,03 & 1,81 & 0,00 & 0,00 & 31,51 \\
\hline $\begin{array}{l}\text { broadleaf } \\
\text { linden, maple } \\
\text { and oak forests }\end{array}$ & 1,73 & 0,00 & 0,00 & 0,00 & 0,00 & 0,00 & 88,61 & 0,00 \\
\hline $\begin{array}{l}\text { broad-leaved } \\
\text { mesophytic } \\
\text { forests }\end{array}$ & 7,79 & 8,52 & 37,28 & 56,06 & 0,00 & 0,00 & 0,00 & 40,96 \\
\hline $\begin{array}{l}\text { south taiga pine } \\
\text { forests with } \\
\text { linden }\end{array}$ & 1,01 & 0,00 & 0,00 & 0,00 & 0,00 & 0,00 & 0,00 & 0,00 \\
\hline $\begin{array}{l}\text { meadows and } \\
\text { arable land in } \\
\text { place } \\
\text { floodplain of } \\
\text { forests }\end{array}$ & 26,18 & 0,00 & 0,00 & 0,00 & 17,89 & 0,00 & 0,00 & 1,26 \\
\hline $\begin{array}{l}\text { meadow steppes } \\
\text { and steppe } \\
\text { forests }\end{array}$ & 2,46 & 0,00 & 0,00 & 0,00 & 28,11 & 81,36 & 0,00 & 0,00 \\
\hline $\begin{array}{l}\text { arable land, } \\
\text { hayfields and } \\
\text { pastures on the } \\
\text { site } \\
\text { floodplain } \\
\text { forests }\end{array}$ & 3,02 & 53,98 & 0,00 & 0,00 & 0,00 & 0,00 & 0,00 & 0,00 \\
\hline $\begin{array}{l}\text { arable land, } \\
\text { hayfields and } \\
\text { pastures }\end{array}$ & 17,67 & 18,74 & 2,15 & 0,00 & 0,00 & 0,00 & 0,00 & 27,17 \\
\hline $\begin{array}{l}\text { arable land, } \\
\text { meadow steppes } \\
\text { and steppe } \\
\text { meadows }\end{array}$ & 12,26 & 0,00 & 0,00 & 0,00 & 52,27 & 14,77 & 11,47 & 0,00 \\
\hline steppe & 0,00 & 0,00 & 0,00 & 0,00 & 0,00 & 3,97 & 0,00 & 0,00 \\
\hline $\begin{array}{ll}\text { oak } & \text { steppe } \\
\text { forests }\end{array}$ & 0,18 & 0,00 & 0,00 & 0,00 & 15,79 & 0,00 & 0,00 & 0,00 \\
\hline
\end{tabular}


1. the arable lands irrigated by a rain

2. vegetation with mosaic impregnations of arable lands

3. arable lands with mosaic impregnations of vegetation

4. boundary listopadny wood

5. boundary coniferous evergreen forest

6. coniferous listopadny or evergreen forest (thin forest)

7. the boundary mised broad-leaved and coniferous forest

8. bushes with mosaic impregnations of a meadow

9. meadows with mosaic impregnations of bushes

10. poor vegetation

11. boundary vegetation, regularly flooded

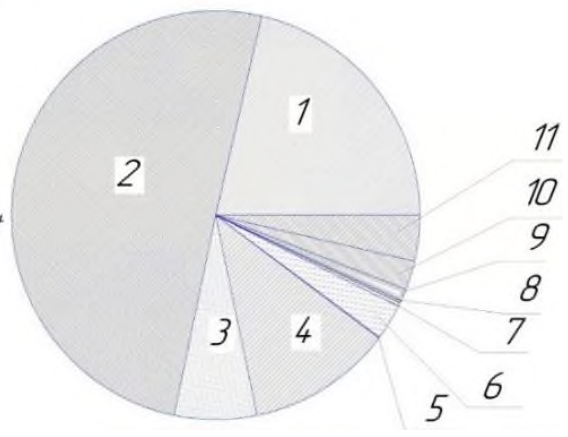

Fig. 1. The result of determining land use types in the floodplain of the Belaya River.

The protective role of the forest is to strengthen the soil with its root system. The ground part of trees and shrubs reduces the erosive power of the water flow by slowing it down. Meanwhile, unforested areas are where the erosion of the coast occurs. Near-river forests and undergrowth contribute to the accumulation of solid runoff transported by the water flow, preventing its erosion, delaying the sediment, turf, and fragments of vegetation in floods, preventing clogging and silting of the flow and floodplain soils. The predominance of woodlands indicates floodplain resistance to the risk of degradation, while arable land, hayfields, and steppes indicate high potential risk of floodplain depletion.

Ratio of areas of various vegetation types to the area of the studied floodplain-channel complexes, in\%

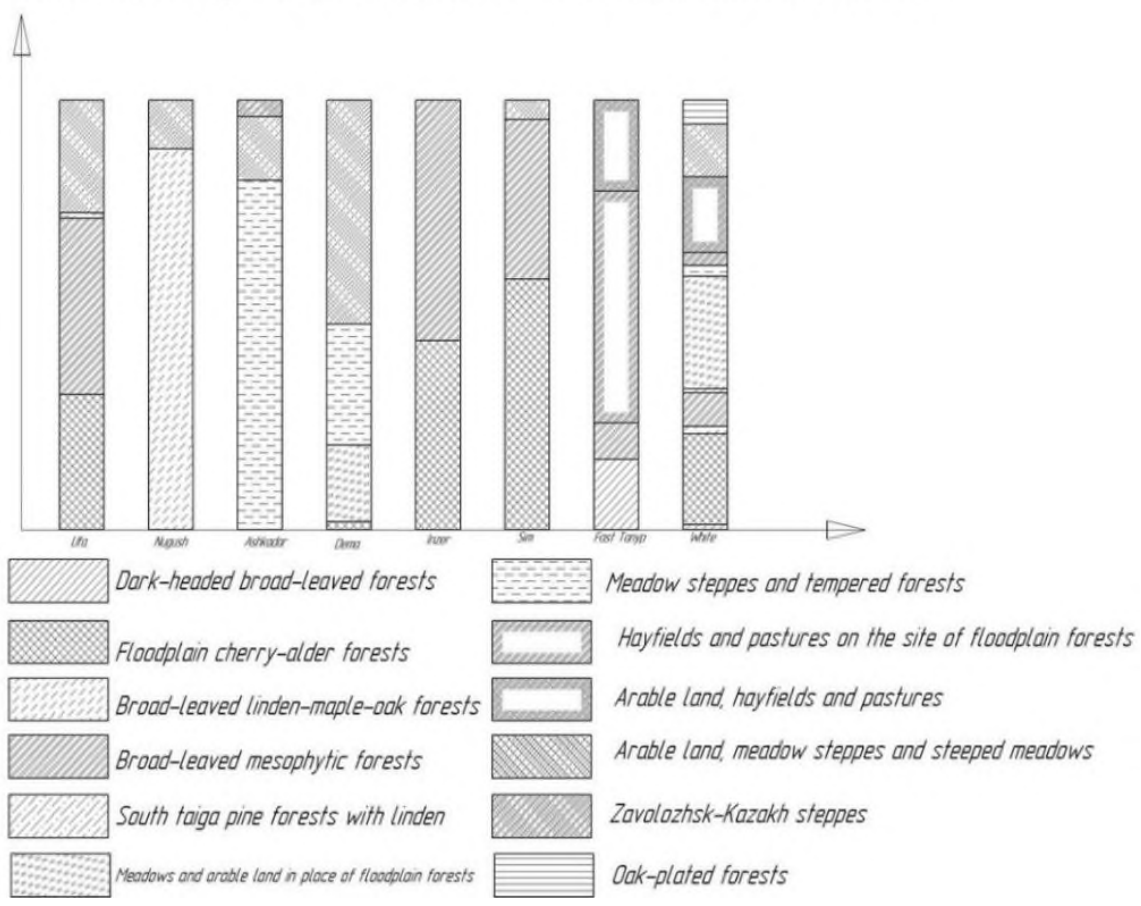

Fig. 2. Histogram of zoning of river floodplains in the Belaya river basin by species composition of vegetation

Thus, given the calculations based on the GIS data presented in Table 1 into a histogram (Figure 2), it can be said that the floodplains of the Sim, Inzer and Ufa rivers are the most 
resistant to depletion, where floodplain cherry-alder and broad-leaved mesophytic forests prevail. As resistant is the the Nugush River floodplain, 88,61\% of which is covered with broad-leaved linden-maple-oak forests.

The floodplain areas of the Rapid Tanyp and Belaya rivers are most at risk: arable land and hayfields occupy about a half of the area. Moreover, about $80 \%$ of the floodplain area of the Ashkadar River is occupied by meadow steppes and steppe forests, which also speaks of exposure to geoecological risk. For the floodplain of the Dema River, meadows, arable land and meadow steppes in the aggregate also occupy about $80 \%$.

It is difficult to quantify the potential risk by assessing the depletion of the floodplainriverbed complex by the plant species composition. We can only talk about its relative values.

\section{Calculation of the risk of depletion of floodplains according to the ecological and hydrological state}

The calculation of geoecological risk is based on the approach to determining the risk of long-term (chronic) exposure (water pollution, depletion of water resources, degradation of the river network). The calculation of the risk of depletion of floodplains based on the ecological and hydrological state was carried out taking into account changes in floodplain areas over the past 10 years, data on the catchment of ground and surface waters, "sealed" areas and the average annual discharge.

The floodplain depletion risk and the coefficient of floodplain depletion were calculated by the following formulas:

$$
\text { Risk F.D }=1-\exp (\ln 0,84 \cdot K 1 \cdot K 2) \text {, }
$$

where $\mathrm{K} 1$ - correction factor dependent on the depletion coefficient (Table 2):

Table 2. The value of the correction factor depending on the coefficient of depletion.

\begin{tabular}{|c|c|}
\hline $\mathbf{K}_{\mathbf{2}}$ & $\mathbf{K}_{\mathbf{1}}$ \\
\hline $0,1-0,5$ & 0,5 \\
\hline $0,5-1,0$ & 1,0 \\
\hline $1,0-1,5$ & 1,5 \\
\hline $1,5-2,0$ & 2,0 \\
\hline $2,0-2,5$ & 2,5 \\
\hline
\end{tabular}

$\mathrm{K} 2$ - coefficient of depletion, calculated by the formula:

$$
K 2=\frac{V 1+V 2}{Q \cdot S \cdot K 3},
$$

where V1 and V2 - surface and groundwater withdrawal, thousand $\mathrm{m} 3 / \mathrm{km} 2$;

$\mathrm{Q}$ - long-term annual average flow rate, $\mathrm{m} 3 / \mathrm{s}$;

$\mathrm{S}$ - modified floodplain area, $\mathrm{km} 2$;

K3 - the correction factor depending on the type of use of the territory (if the site has "sealed territories" (areas covered by asphalt or concrete), then $K 3=1$, otherwise $K 3=0,6$ ). In this case, the coefficient is 1 only for the Belaya River. 
According to the available data on the daily hydrological characteristics of the Belaya River in the studied floodplains of the rivers (Belaya, Bystry Tanyp, Inzer, Ufa, Dema, Sim, Ashkadar, Nugush), the average annual discharge was calculated for the 2005-2015 period.

\section{Results}

Based on the calculations of the mean annual discharge of the Belaya River for the catchments of the Russian hydrometeorological service in the Republic of Bashkortostan, the mean long-term values of the floodplain depletion coefficient K2 and the risk of water resources depletion Risk F.D. for the entire floodplain of the Belaya River and for the floodplains of each tributary of the Belaya River separately were determined in Figure 3.

\begin{tabular}{|c|c|c|c|c|c|c|c|c|}
\hline K2 & 0.035 & 0,267 & 0,805 & 0,0133 & 0.437 & 0,085 & 5.963. & 4.195 \\
\hline \multirow[t]{2}{*}{ Risk F.D. } & 6.163 & 45,487 & 130,95 & 2,321 & 73,428 & 14,773 & & 518.8 \\
\hline & Belaya & $\begin{array}{l}\text { Bystry } \\
\text { Tanyp }\end{array}$ & Inser & Ufa & Dema & Sim & Ashkadar & ugush \\
\hline
\end{tabular}

Fig. 3. Calculated factors and values of the risk of depletion for the Belaya River floodplain.

As can be seen from Table 3, the floodplains of Ashkadar, Nugush and Inzer are most at risk for the ecological and hydrological state.

When comparing estimates of the depletion of floodplain areas according to the applied methods (species composition of forest cover and vegetation and ecological and hydrological status), the floodplain area of the Ashkadar River was classified as at risk of degradation. The analysis showed that different sections of the floodplains are subject to different types of risk, and only an integrated approach can give a complete picture of the potential danger.

\section{Discussion and conclusions}

Thus, the obtained data on the assessment of the geoecological risk of depletion of the floodplain-riverbed complex using the methods of geoinformation modeling made it possible to identify the areas of floodplain areas that are most at risk of degradation and require environmental protection measures.

The development of mapping and processing of satellite information in recent years makes it possible to provide more detailed information for individual parts of landscapes, which increases the accuracy of the geoecological assessment of these landscapes in many respects and allows for a comprehensive multicomponent assessment of changes in territories. The planning of environmental protection measures and the development of river floodplains must necessarily be based on the risk assessment of depletion of quantitative and qualitative changes in floodplains. The proposed methodology allows not only to assess the risk of the current state of the floodplain, but also give a predictive assessment of floodplain changes if the calculated parameters of the planned interventions in the development of floodplains are known (such as building on the floodplain or riverbed works).

\section{References}

1. V. Goswami, D. Vasudev, B. Joshi, P. Hait, P Sharma, Coupled effects of climatic forcing and the human footprint on wildlife movement and space use in a dynamic 
floodplain landscape Science of The Total Environment (2021) DOI: 10.1016/j.scitotenv.2020.144000

2. V. M. Gaponov, A. N. Elizaryev, S. G. Aksenov, A. Longobardi, Analysis of trends in annual time series of precipitation in the Republic of Bashkortostan, Conference Series: Earth and Environmental Science 350, 012003 (2019) DOI: 10.1088/1755$1315 / 350 / 1 / 012003$

3. N. V. Trung, J. H. Choi, S. J. Won, Monitoring floodplain area of Tonle Sap Lake, Cambodia using multi-temporal ALOS PALSAR data, 3rd International Asia-Pacific Conference on Synthetic Aperture Radar (APSAR), p 524-530 (2011)

4. I. Nichersu, E. Marin, C. Trifanov, Environment Management Risk Programs in Northern Coastal Zone of Black Sea - the Romanian Sector, Proceedings of the Ninth International Conference on the Mediterranean Coastal Environment MEDCOAST 09 - 10-14, p 579-590 (2009)

5. K. Youjung, N. Galen, Advancing scenario planning through integrating urban growth prediction with future flood risk models, Ecological Engineering 158 (2020)

6. Y. J. Kwak, R. Pelich, Fractional Floodwater-Pixel Fusion for Emergency Response Using ALOS-2 and Sentinel-1 IEEE Aerospace Conference (2019)

7. S. Schindler, F. O’Neill, M. Biro, C. Damm, V. Gasso, et.al. Multifunctional floodplain management and biodiversity effects: a knowledge synthesis for six European countries, Biodiversity and Conservation 25, 1349-1382 (2016)

8. T. Silva, M. Costa, E. Novo, J. Melack, A multisensor, multitemporal approach for monitoring herbaceous vegetation growth in the Amazon floodplain, 7th International Workshop on the Analysis of Multi-temporal Remote Sensing Images (2013)

9. C. Huang, Y. Chen, J. Yu, J. Wu, Detecting floodplain inundation frequency using MODIS time-series imagery, 2012 First International Conference on AgroGeoinformatics (Agro-Geoinformatics) (2013)

10. S. Benger, Remote sensing of ecological responses to changes in the hydrological cycles of the tonle sap, Cambodia IEEE International Geoscience and Remote Sensing Symposium (2008)

11. J. Lacassie, J. Ruiz-Del-Solar, Application of artificial neural networks to the geochemical study of an impacted fluvial system, The 2010 International Joint Conference on Neural Networks (IJCNN) (2010)

12. O. Ozcan, S. Akay, Modeling Morphodynamic Processes in Meandering Rivers with UAV-Based Measurements, IGARSS 2018 - 2018 IEEE International Geoscience and Remote Sensing Symposium (2018)

13. L. Kooistra, E. Kuilder, C. Mücher, Object-based random forest classification for mapping floodplain vegetation structure from nation-wide CIR AND LiDAR datasets, 6th Workshop on Hyperspectral Image and Signal Processing: Evolution in Remote Sensing (WHISPERS) (2014)

14. J. Brus, V. Pechanec, H. Kilianova, I. Machar, The evolution of the floodplain forests as indicators of landscape changes in the alluvium of the Morava River, 21st International Conference on Geoinformatics (2013)

15. J. Betbeder, V. Gond, F. Frappart, N. Baghdadi, G. Briant, E. Bartholome, Mapping of Central Africa Forested Wetlands Using Remote Sensing, IEEE Journal of Selected Topics in Applied Earth Observations and Remote Sensing 7 (2014) 